\title{
EVALUATION OF SOIL RESILIENCE TO ANTHROPOPRESSURE IN LOSIE VILLAGE (LOWER BESKIDS MTS) - PRELIMINARY RESULTS
}

\author{
AGNIESZKA NOWAK, NATALIA TOKARCZYK
}

Jagiellonian University, Institute of Geography and Spatial Management, ul. Gronostajowa 7, 30-387 Cracow, Poland, e-mail: ag.nowak@uj.edu.pl,n.tokarczyk@uj.edu.pl

\begin{abstract}
Nowak A., Tokarczyk N.: Evaluation of soil resilience to anthropopressure in Łosie village (Lower Beskids Mts) - preliminary results. Ekológia (Bratislava), Vol. 32, No. 1, p. 138-147, 2013.

This paper presents the preliminary results of research on soil resilience to anthropopressure in Łosie village (Lower Beskids Mts). The considered risks included three features which reflect soil resilience: predicted soil loss caused by water erosion, mechanical and physico-chemical filtration capacities. The average annual rate of soil loss was calculated based on the Revised Universal Soil Loss Equation (RUSLE). Analyses of mechanical and physico-chemical filtration capacities of soils were conducted on the basis of algorithms which took into account the soil texture class and groundwater table class. The results confirmed that the highest predicted soil loss takes place within arable lands, particularly those located on slopes - with up and down tillage. During the period from 1997 to 2009, predicted soil loss decreased by $57 \%$ due to the decline in the percentage of arable land in the research area. It was found that the introduction of cross-slope tillage within arable lands could decrease overall predicted soil loss up to $67 \%$. Areas with the lowest mechanical filtration capacities were located on slopes and related to sandy clay soils whereas the areas with the lowest physico-chemical filtration capacities were situated in valley bottoms and are mainly due to the shallow level of the groundwater table. Finally, it was noted that the different types of analyzed risk do not overlap nor even do they correspond with each other, which is conditioned by different features of the environment that were taken into consideration. The obtained results have shown how important sustainable spatial planning evaluation of various types of environmental resilience is.
\end{abstract}

Key words: soil resilience, water erosion, filtration capacities, RUSLE, Lower Beskids Mts.

\section{Introduction}

Sustainable development, in which spatial planning needs to be adjusted to environmental conditions, is a new development strategy of the EU. The spatial planning process should always be preceded by a rigorous assessment of the natural environment. This is especially crucial in a mountain environment, as it is one of the most fragile environments. However, agreement on proper land use is nowadays a challenge for the different stakeholders involved, such as planners, investors and local communities. Accounting for the different types of risk in the evaluation of specific landscape elements is an important step towards sustainable land use. Environmental resilience is a main feature which should be evaluated to distinguish the appropriate spatial development zones. 
According to Holling, (1973) "resilience determines the persistence of relationships within a system and is a measure of the ability of the system to absorb changes". In other words it is "the capacity of a system to respond to a perturbation or disturbance by resisting damage and recovering quickly" (Folke et al., 2002). When the "disturbances have sufficient magnitude or duration they may force a system to reach a threshold" and then the deterioration of the system begins (Folke et al., 2002.).

Resilience depends strictly on the type of risk as well as on the element of environment on which the risk stimulus affects. That is why only partial resilience should be considered and only the sum of partial resilience of different environment elements should be identified as environmental resilience. With this approach, resilience of soil, groundwater, surface water, air or flora should be studied individually.

There are many different approaches used to support spatial planning system. One of them is Multicriteria Landscape Assessment and Optimisation (MULBO) created by Meyer and Grabaum (1998). It is a GIS-based method for landscape assessment and optimisation to support the decision-making process in spatial planning. Grabaum et al. (2005) compiled different methods for assessment of particular regulatory functions of environment which include a supply and protective function of groundwater, climatogenic function, regulation of runoff, water and wind erosion of soils as well as soil filtration capacities. These regulatory functions are responsible for maintaining the balance in the environmental system. A sustainable environment is, at the same time, a resilient environment, making these features appropriate for environmental resilience assessment. Likewise, Tracz (2004) presents a set of methods which may be applied to evaluate environmental resilience to degradation. One of them is the evaluation of soil resilience to water erosion. Research on water erosion of soils were, for a long time, the subject of interest for many researchers. Wischmeier and Smith (1978) formulated the Universal Soil Loss Equation (USLE) to predict soil loss caused by water erosion which was later changed by Renard et al. (1997) to the Revised Universal Soil Loss Equation (RUSLE). The equations were used repeatedly for predicted soil loss calculation in different regions of the world (Arghinus, C., Arghinus, V., 2011; Bosco et al., 2009; Igwe et al., 1999; Lastoria et al., 2008; Yue-qing et al., 2009). Also, in the mountain areas of Poland such research was undertaken (Demczuk, 2009; Drzewiecki, 2006; Koreleski, 2008).

Soil is a very important element of the environment which, on one the hand is extremely vulnerable to anthropopressure, and on the other hand provides protection of other parts of the environment. This is especially evident in the filter function of soils. Not only are soils responsible for mechanical filtration and immobilization of pollutants, but also harmful substances are decomposed in them. That is why soil filtration capacities may be used as an indicator of soil resilience. The higher filtration capacities are, the higher the soil resilience is to pollution. On the contrary, predicted soil loss caused by water erosion account for an indicator of the vulnerability of soils itself - the higher the predicted soil loss, the less resilient to environmental erosion.

The aim of the study was to evaluate soil resilience to anthropopressure. Research included three features which reflect soil resilience such as predicted soil loss, mechanical and physico-chemical filtration capacities. Predicted soil loss enable assessment of actual spatial management whereas mechanical and physico-chemical filtration capacities are potential features based on characteristics of the environment. 


\section{Material and methods}

The evaluation of soil resilience to anthropopressure was conducted for the part of Ropa municipality - Łosie village (Fig. 1). The smallest unit of administrative division was chosen for analysis because the spatial planning process at a local level concerns municipalities and their parts. Characteristic features of the study area are presented in Table 1. Łosie village is located in the Lower Beskids Mts, which is a part of the Outer Western Carpathians. This region is built of the Carpathian flysch and the main tectonic unit there is the Magura Nappe. The elevation in Łosie ranges from 350 to $662 \mathrm{~m}$ a.s.l. There are two distinct climatic vertical zones: moderate warm and moderate cool. The mean annual sum of precipitation ranges from 800 to $900 \mathrm{~mm}$ and the majority of precipitation occurs in summer (Obrębska-Starklowa, 1983). The dominant type of soil in Łosie is Eutric Cambisols, in particular: sandy loam, loam, clay loam, sandy clay, silt and silt loam. There are two altitudinal zones in the research area: the foothill vertical zone and lower forest vertical zone covered by the Carpathian beech forest (Dentario glandulosae-Fagetum).

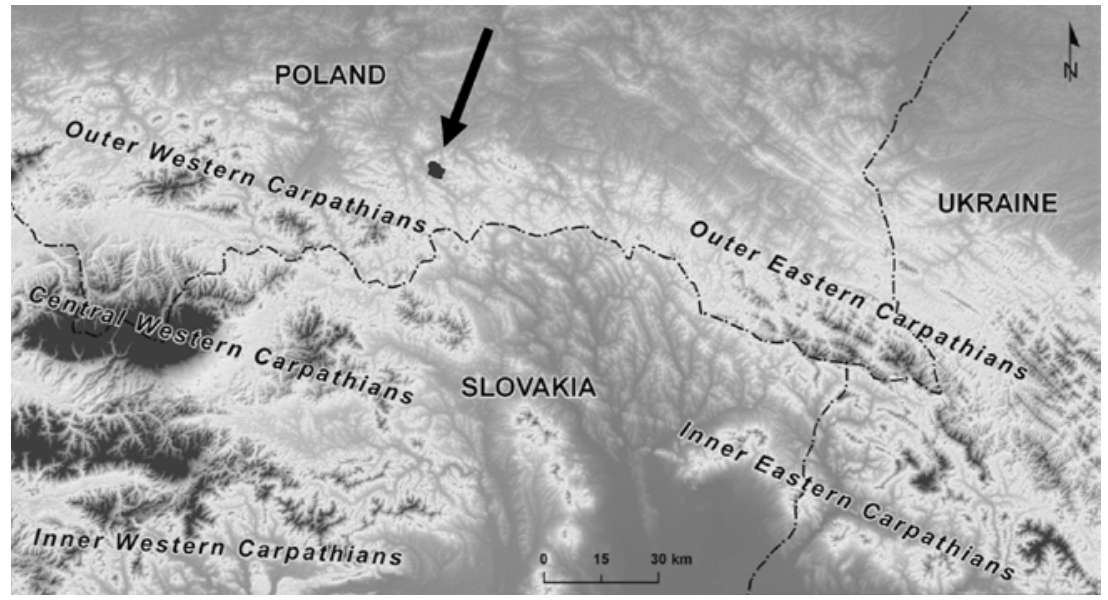

Fig. 1. Location of the study area.

$\mathrm{T} \mathrm{a} \mathrm{ble} 1$. The characteristic features of study area.

\begin{tabular}{|l|l|}
\hline \multicolumn{1}{|c|}{ Study area } & \multicolumn{1}{c|}{ Losie village } \\
\hline Physicogeographical subregion & Lower Beskids (Outer Western Carpathians) \\
\hline Main tectonic unit & Magura nappe \\
\hline Altitude range & $350-662 \mathrm{~m}$ a.s.l. \\
\hline Climatic vertical zones & moderate warm, moderate cool \\
\hline Annual sum of precipitation & $800-900 \mathrm{~mm}$ \\
\hline Dominant type of soil & Eutric Cambisols \\
\hline Altitudinal zones & foothill vertical zone, lower forest vertical zone \\
\hline Dominant forest community & Carpathian beech forest (Dentario glandulosae-Fagetum) \\
\hline
\end{tabular}

T a b le 2. Land use changes between 1997 and 2009.

\begin{tabular}{|l|c|c|}
\hline \multirow{2}{*}{\multicolumn{1}{|c|}{ Land use }} & \multicolumn{2}{c|}{ Percentage of the area (\%) } \\
\cline { 2 - 3 } & $\mathbf{1 9 9 7}$ & $\mathbf{2 0 0 9}$ \\
\hline Arable lands & 5.0 & 2.5 \\
\hline Grasslands & 27.9 & 28.0 \\
\hline Forest & 67.1 & 69.5 \\
\hline
\end{tabular}


The majority of Łosie is occupied by forest, accounting for $69.5 \%$ of its total area (Table 2). A significant percentage of the area at lower altitudes is covered by grasslands. Built-up areas are located in the valley bottoms whereas arable lands occupy both valley bottoms and slopes (Figs 2, 3). In the years 1997 and 2009, the area of arable lands decreased from 5 to $2.5 \%$ (Table 2). These changes are the consequence of the socio-economic transformation of Poland. As a result of EU membership, afforestation of land supported financially by the EU has become a common decision among land owners. Furthermore, the process of land abandonment is more and more popular since land cultivation and livestock farming have become unprofitable. Despite EU subsidies for agriculture in mountain areas farm production costs often exceed expected profits.

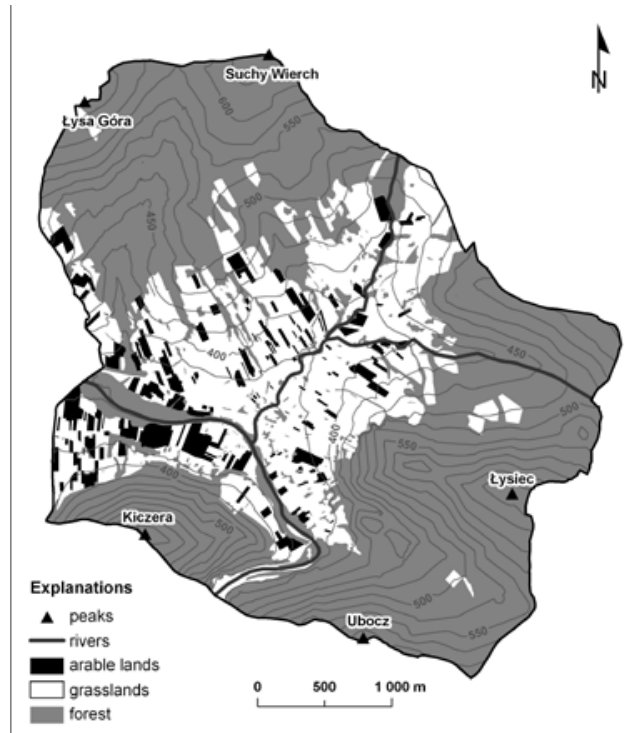

Fig. 2. Land use in 1997.

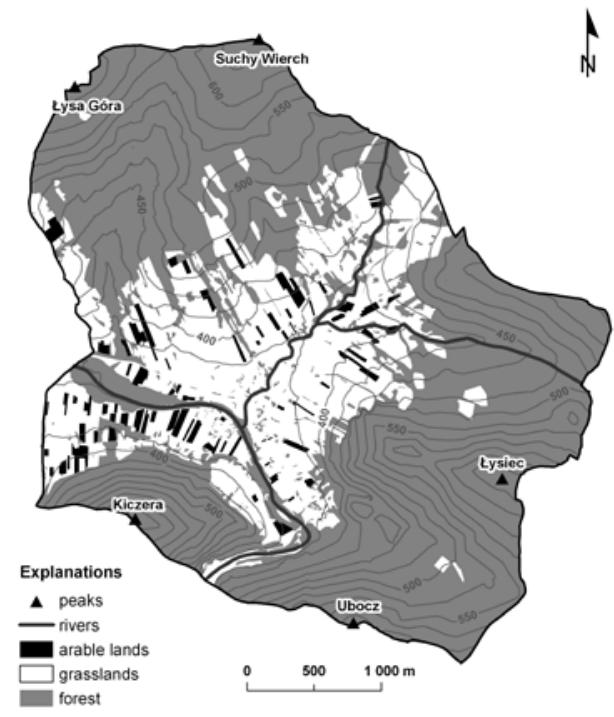

Fig. 3. Land use in 2009.

The research included the calculation of predicted soil loss caused by water erosion as well as an estimation of mechanical and physico-chemical filtration capacities of soils. The study used data consisting of a digital elevation model (TIN), orthophotos, and soil and agrarian maps. Additionally, a land use map was derived from the ortophotos through digitalization. Also, a hydrological paper map required digitalization in order to combine it together with other materials. A map overlapping technique was used for the analyses.

The soil erosion loss analysis was conducted for two different time periods - 1997 and 2009. The sheet and rill erosion rate calculation was based on the Universal Soil Loss Equation (USLE) formulated by Wischmeier and Smith (1978) and then changed by Renard et al. (1997) to the Revised Universal Soil Loss Equation (RUSLE). This equation predicts the long term average annual rate of erosion on a field slope based on rainfall patterns, soil type, topography, crop system and management practices (Stone, Hilborn, 2000). The average annual rate of soil loss caused by erosion was calculated as follows:

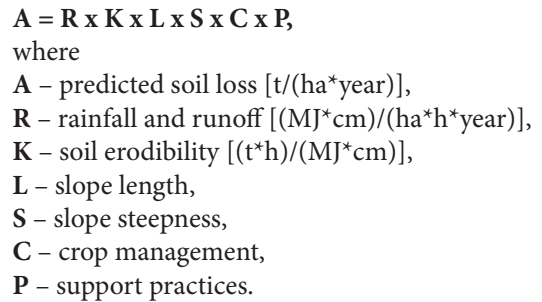


Rainfall and runoff factor (R) was a constant value calculated by Demczuk (2009) for the nearby research station in Szymbark and equalled $108.2\left(\mathrm{MJ}^{\star} \mathrm{cm}\right) /\left(\mathrm{ha}^{\star} \mathrm{h}^{\star}\right.$ year). Soil erodibility factor $(\mathrm{K})$ depending on the soil textural class was attributed to every patch of different soil type (Table 3). Topography factors, i.e. slope length (L) and slope steepness (S), were assigned to each patch of different land use. L-factor values for specific slope length intervals were calculated on the base of the formula proposed by Renard et al. (1997) and S-factor values were derived from the paper by Grabaum et al. (2005) (Tables 4, 5).

T a b le 3. Values of soil erodibility factor (K) depending on the soil textural class according to Demczuk (2009).

\begin{tabular}{|c|c|}
\hline Textural class & Soil erodibility factor (K) \\
\hline Sandy loam & 0.2898 \\
\hline Loam & 0.3239 \\
\hline Clay loam & 0.3917 \\
\hline Sandy clay & 0.4609 \\
\hline Silt & 0.4805 \\
\hline Silt loam & 0.5101 \\
\hline
\end{tabular}

T a b le 4. Values of slope length factor (L) calculated on the base of formula of Renard et al. (1997).

\begin{tabular}{|c|c|c|}
\hline Slope length (m) & \multicolumn{2}{|c|}{ L-factor } \\
\hline & $>\mathbf{1 0}^{\circ}$ & $<\mathbf{1 0}^{\circ}$ \\
\hline 10 & 0.6 & 0.7 \\
\hline 20 & 0.9 & 1 \\
\hline 30 & 1.2 & 1.1 \\
\hline 40 & 1.4 & 1.3 \\
\hline 50 & 1.6 & 1.4 \\
\hline 60 & 1.8 & 1.5 \\
\hline 70 & 2 & 1.6 \\
\hline 80 & 2.2 & 1.7 \\
\hline 90 & 2.3 & 1.8 \\
\hline 100 & 2.5 & 1.8 \\
\hline 120 & 2.8 & 2 \\
\hline 140 & 3 & 2.1 \\
\hline 160 & 3.3 & 2.2 \\
\hline 180 & 3.5 & 2.3 \\
\hline 200 & 3.7 & 2.4 \\
\hline 220 & 4 & 2.5 \\
\hline 240 & 4.2 & 2.6 \\
\hline 260 & 4.4 & 2.7 \\
\hline 280 & 4.6 & 2.8 \\
\hline 300 & 4.8 & 2.8 \\
\hline 350 & 5.2 & 3 \\
\hline
\end{tabular}

\begin{tabular}{|c|c|c|}
\hline Slope length (m) & \multicolumn{2}{|c|}{ L-factor } \\
\hline & $>\mathbf{1 0}^{\circ}$ & $<\mathbf{1 0}^{\circ}$ \\
\hline 400 & 5.7 & 3.2 \\
\hline 450 & 6.1 & 3.3 \\
\hline 500 & 6.5 & 3.5 \\
\hline 550 & 6.9 & 3.6 \\
\hline 600 & 7.2 & 3.7 \\
\hline 650 & 7.6 & 3.9 \\
\hline 700 & 7.9 & 4 \\
\hline 750 & 8.3 & 4.1 \\
\hline 800 & 8.6 & 4.2 \\
\hline 850 & 8.9 & 4.3 \\
\hline 900 & 9.2 & 4.4 \\
\hline 950 & 9.5 & 4.5 \\
\hline 1000 & 9.8 & 4.6 \\
\hline 1050 & 10.1 & 4.7 \\
\hline 1100 & 10.4 & 4.8 \\
\hline 1150 & 10.7 & 4.9 \\
\hline 1200 & 11 & 4.9 \\
\hline 1250 & 11.3 & 5 \\
\hline 1300 & 11.5 & 5.1 \\
\hline 1350 & 11.8 & 5.2 \\
\hline 1400 & 12 & 5.3 \\
\hline
\end{tabular}

T a b l e 5. Values of slope steepness factor (S) according to Graubaum et al. (2005).

\begin{tabular}{|c|c|}
\hline Slope steepness $\left(^{\circ}\right)$ & S -factor \\
\hline 3 & 0.2 \\
\hline 4 & 0.3 \\
\hline 5 & 0.5 \\
\hline 6 & 0.6 \\
\hline 7 & 0.7 \\
\hline 8 & 0.8 \\
\hline 9 & 1 \\
\hline 10 & 1.2 \\
\hline 11 & 1.3 \\
\hline 12 & 1.5 \\
\hline 13 & 1.7 \\
\hline 14 & 2 \\
\hline 15 & 2.2 \\
\hline
\end{tabular}

\begin{tabular}{|c|c|}
\hline Slope steepness $\left(^{\circ}\right)$ & S -factor \\
\hline 16 & 2.4 \\
\hline 17 & 2.6 \\
\hline 18 & 2.9 \\
\hline 19 & 3.2 \\
\hline 20 & 3.5 \\
\hline 21 & 3.8 \\
\hline 22 & 4.1 \\
\hline 23 & 4.4 \\
\hline 24 & 4.7 \\
\hline 26 & 5.4 \\
\hline 28 & 6.1 \\
\hline 30 & 6.8 \\
\hline
\end{tabular}


The value of crop management factor (C) was attributed according to the land use type (Table 6). However, due to the difficulty in distinguishing particular crops, to all arable lands values for potatoes proposed by Demczuk (2009) were assumed. Finally, support practices factor (P) equaled 1 for the whole study area as no support practice to reduce soil loss caused by water erosion was taken and the tillage was conducted up and down slope. For comparison, the case of cross-slope tillage was tested in which, depending on slope steepness, support practices factor (P) ranged from 0.5 to 0.9 .

T a b l e 6. Values of crop management factor (C) depending on the land use according to Demczuk (2009).

\begin{tabular}{|l|c|}
\hline Land use & Crop management factor (C) \\
\hline Arable lands & 0.30182 \\
\hline Grasslands & 0.00087 \\
\hline Forest & 0.00001 \\
\hline
\end{tabular}

Analyses of mechanical and physico-chemical filtration capacities of soils were conducted on the base of algorithms proposed by Altmann et al. (1992). For calculation of both mechanical and physico-chemical filtration capacities, soil texture class and groundwater table class were used. Equations applied to calculate these values are presented below:

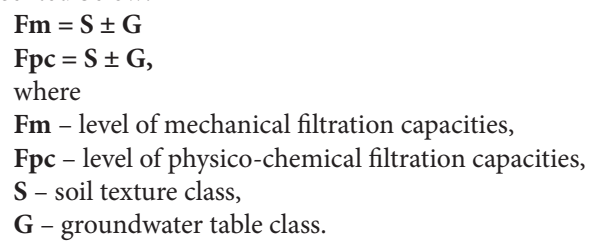

The soil textural class is crucial as it estimates filtration capacities and determines the appropriate filtration capacities class. However, various types of soils react differently, depending on the type of pollution. That is why, depending on the type of investigated filtration capacities, classes are different (Table 7). They may be modified by the depth of the groundwater table class (Table 8). Additionally, in case of mechanical filtration capacities, climatic water balance surplus higher than $300 \mathrm{~mm}$ would increase their level. However within the whole study area, climatic water balance surplus was lower than $300 \mathrm{~mm}$ so the values remained unchanged.

T a b l e 7. Filtration capacities class depending on the soil textural class according to Graubaum et al. (2005).

\begin{tabular}{|l|c|c|}
\hline \multirow{2}{*}{ Textural class } & \multicolumn{2}{|c|}{ Filtration capacities class } \\
\cline { 2 - 3 } & Mechanical & Physico-chemical \\
\hline Sandy loam & 4 & 3 \\
\hline Loam & 3 & 3 \\
\hline Clay loam & 3 & 3 \\
\hline Silt & 3 & 4 \\
\hline Silt loam & 4 & 4 \\
\hline Sandy clay & 2 & 5 \\
\hline
\end{tabular}

Notes: classes of filtration capacities: 2 - very low, 3 - medium, 4 - high, 5 - very high.

T a b l e 8. Modification of filtration capacities class depending on the depth of groundwater table according to Graubaum et al. (2005).

\begin{tabular}{|l|c|c|}
\hline \multirow{2}{*}{ Depth of groundwater table $(\mathbf{m})$} & \multicolumn{2}{|c|}{ Filtration capacities class } \\
\cline { 2 - 3 } & Mechanical & Physico-chemical \\
\hline$<0.8$ & -1 & -2 \\
\hline $0.8-2$ & 0 & -1 \\
\hline $2-10$ & 0 & 0 \\
\hline $10-30$ & +1 & +1 \\
\hline$>30$ & +2 & +2 \\
\hline
\end{tabular}




\section{Results and discussion}

As a result, maps of predicted soil loss caused by water erosion for the years 1997 and 2009 were created (Figs 4,5 ). The highest predicted soil loss was, in both cases, in arable lands. It was lower in grasslands and the lowest in forest areas (Table 9). Predicted soil loss decreased by $57 \%$ during this period of time, which is a result of changes in land use, i.e. a decrease of arable land area. All mean values of the erosion rate also decreased, which is an effect of patches area reduction (Table 9).
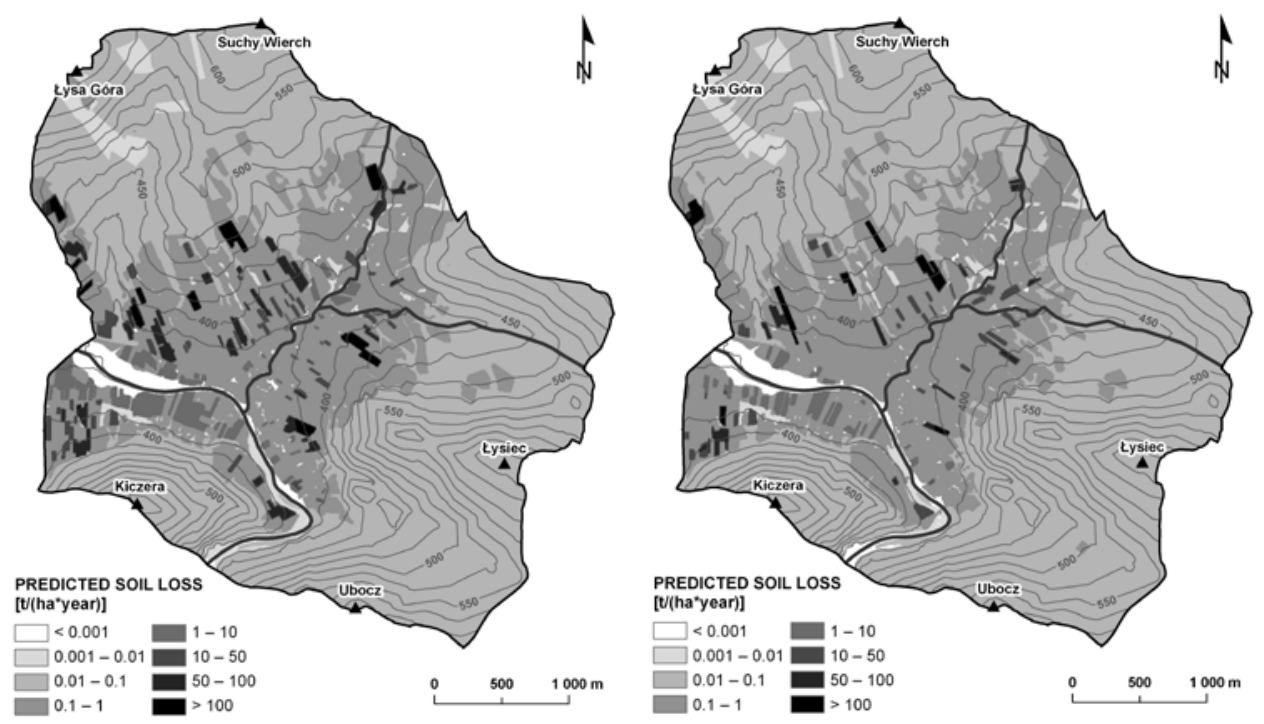

Fig. 4. Predicted soil loss caused by water erosion in 1997 Fig. 5. Predicted soil loss caused by water erosion in 2009.

T a b l e 9. Predicted soil loss caused by water erosion for year 1997 and 2009.

\begin{tabular}{|c|c|c|c|c|c|c|c|c|}
\hline \multirow{4}{*}{ Land use } & \multirow{3}{*}{\multicolumn{2}{|c|}{$\begin{array}{c}\text { Erosion } \\
\text { t/year }\end{array}$}} & \multicolumn{6}{|c|}{ Rate of erosion } \\
\hline & & & \multicolumn{2}{|c|}{ Mean } & \multicolumn{2}{|c|}{ Max. } & \multicolumn{2}{|c|}{ Min. } \\
\hline & & & \multicolumn{6}{|c|}{ t/(ha*year $)$} \\
\hline & 1997 & 2009 & 1997 & 2009 & 1997 & 2009 & 1997 & 2009 \\
\hline Arable lands & 3049 & 1660 & 34.10 & 30.80 & 164.02 & 216.75 & 1.91 & 1.51 \\
\hline Grasslandss & 488 & 359 & 0.90 & 0.61 & 10.21 & 5.41 & 0.01 & 0.02 \\
\hline Forest & 50 & 40 & 0.55 & 0.34 & 11.38 & 5.76 & 0.00 & 0.00 \\
\hline Total & 3587 & 2060 & 2.73 & 1.58 & - & - & - & - \\
\hline
\end{tabular}

Additionally, a trial of landscape optimisation was undertaken. Introduction of cross-slope tillage within arable lands would decrease overall predicted soil loss by $67 \%$ (Table 10).

In general, the values of predicted soil loss calculated on the basis of assumptions described above correspond to the results obtained by Demczuk (2009) for Bystrzanka catchment. However, measurements of the research plots indicate that these values are almost three ti- 
mes higher than the actual size of the water erosion (Demczuk, 2009). Nevertheless, the calculated values provide some insight into the spatial distribution of soil erosion risk and enable comparisons between specific patches.

T a b l e 10. Predicted soil loss caused by water erosion for year 2009 in case of up\&down and cross slope tillage.

\begin{tabular}{|c|c|c|c|c|c|c|c|c|}
\hline \multirow{4}{*}{ Land use } & \multirow{3}{*}{\multicolumn{2}{|c|}{$\begin{array}{c}\text { Erosion } \\
\text { t/year }\end{array}$}} & \multicolumn{6}{|c|}{ Rate of erosion } \\
\hline & & & \multicolumn{2}{|c|}{ Mean } & \multicolumn{2}{|c|}{ Max. } & \multicolumn{2}{|c|}{ Min. } \\
\hline & & & \multicolumn{6}{|c|}{ t/(ha* year) } \\
\hline & up\&down & cross slope & up\&down & cross slope & up\&down & cross slope & up\&down & cross slope \\
\hline Arable lands & 1660 & 1110 & 30.80 & 22.88 & 216.75 & 195.86 & 1.51 & 1.04 \\
\hline Grasslandss & 359 & 359 & 0.61 & 0.61 & 5.41 & 5.41 & 0.02 & 0.02 \\
\hline Forest & 40 & 40 & 0.34 & 0.34 & 5.76 & 5.76 & 0.00 & 0.00 \\
\hline Total & 2060 & 1509 & 1.58 & 1.12 & - & - & - & - \\
\hline
\end{tabular}

The location of zones characterized by different level of mechanical filtration capacities is presented in Fig. 6. Areas with the lowest mechanical filtration capacities are located on slopes and are marked by sandy clay soils, whereas the highest level of mechanical filtration capacities is in the valley bottoms where the dominant type of soils are sandy loam and silt loam.

Figure 7 shows zones of different levels of physico-chemical filtration capacities. The lowest physico-chemical filtration capacities which simultaneously occur in areas of the lowest resilience are situated in valley bottoms and result mainly from the shallow level of the groundwater table. The highest filtration capacities are characteristic of slopes covered by sandy clay, silt and silt loam.

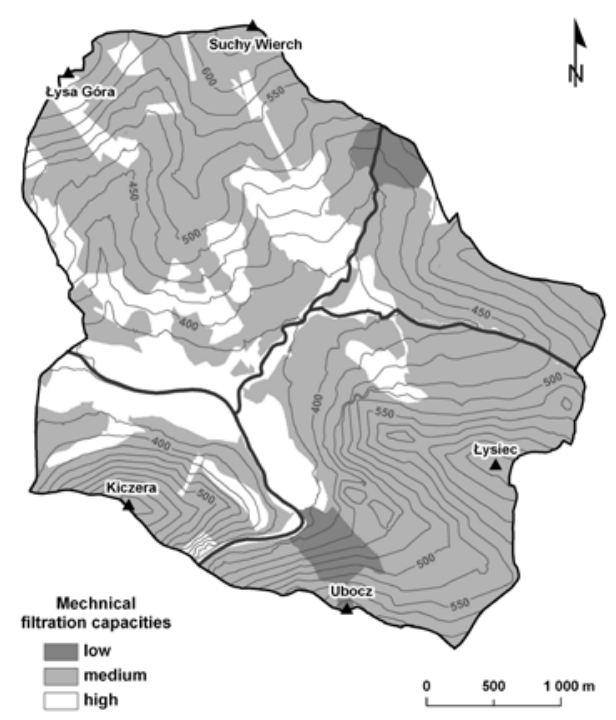

Fig. 6. Mechanical filtration capacities of soils.

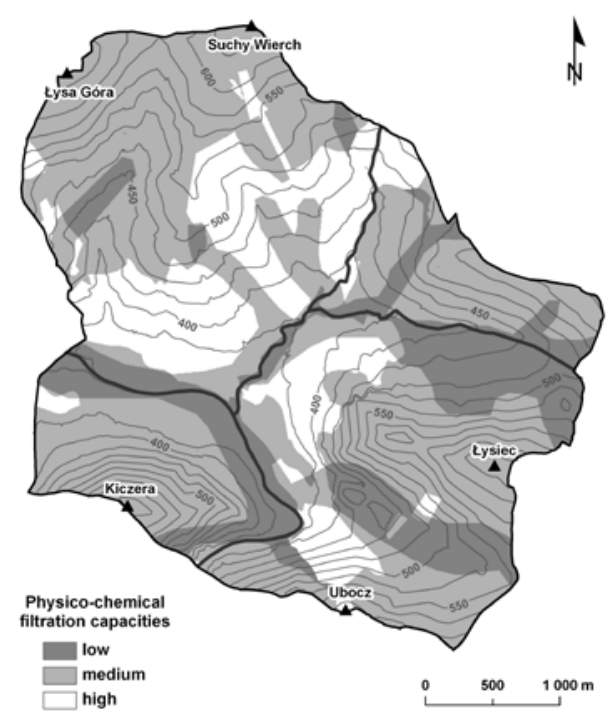

Fig. 7. Physico-chemical filtration capacities of soils. 
Additionally, different kinds of predicted risks - high rate of erosion, low mechanical and physico-chemical filtration capacities - are combined on one map (Fig. 8). It is worth emphasizing that different types of risk presented in Fig. 8 do not overlap nor even do they correspond with each other, which should be an important detail for spatial planners.

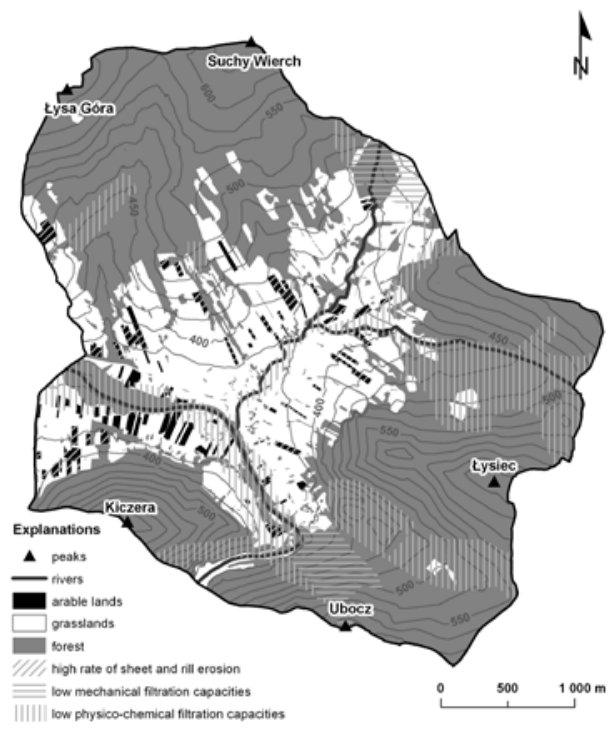

Fig. 8. Different kinds of predicted risks.

\section{Conclusion}

To sum up, the presented results provide an overview of the soil resilience distribution in Łosie village. The main advantage of the presented study is the combination of different features of soil resilience. It is crucial that the zones of particular resilience types are distributed independently of each other and that what is conditioned by different features of the environment are taken into consideration in the analyses. It is especially crucial in the spatial planning process to know precisely in which way a particular pressure threatens the environment and which environmental features are unaffected. Depending on the target land use, more area could require exclusions from specific types of use, or, on the contrary, a certain activity may endanger only one type of environmental feature and only this one should be taken into consideration. According to the spatial planning goal, other kinds of soil features e.g. immobilization and transformation capacities as well as different types of pressure may be considered.

However, this small piece of research in the field of soils has shown how complex an issue environmental resilience is. Even different types of soil resilience were found to have a distinct density. In other environmental elements this spatial distribution of resilience would be much more diverse, which is why it is important to include the various types of resilience during environmental resilience evaluation. 


\section{Acknowledgements}

The preliminarly results published in this paper were presented at Forum Carpaticum 2012. We would like to thank Dr. Burghard Meyer who was so kind as to provide us with the MULBO manual.

\section{References}

Altmann, R., Schreiber K.F. \& Thöle R. (1992). Filtering, buffering and transformation functions (in German). In R. Marks, M.J. Müller, H. Leser \& H.J. Klink (Eds.), Instructions for assessment capacities of landscape sustainability (pp. 65-74). Trier: Zentralausschuß für deutsche Landeskunde, Selbstverlag.

Arghinus, C. \& Arghinus V. (2011). The quantitative estimation of the soil erosion using USLE type ROMSEM model. Case-study - the Codrului Ridge and Piedmont (Romania). Carpathian Journal of Earth and Environmental Sciences, 6(2), 59-66.

Bosco, C., Rusco, E., Montanarella, L. \& Panagos P. (2009). Soil erosion in the Alpine area: risk assessment and climate change. Studi Trentini di Scienze Naturali, 85, 117-123.

Demczuk, P. (2009). Conform model USLE to automatic mapping intensity of soil erosion in the Bystrzanka Mountain Catchment (Flysh Carpathian) (in Polish). In W. Bochenek \& M. Kijowska (Eds.), The integrated monitoring of the environment (pp. 239-244). Szymbark: IGiPZ PAN.

Drzewiecki, W. (2006). GIS and remote sensing data application to the assessment of land-use conditions (in Polish). Geoinformatica Polonica, 8, 7-22.

Folke, C., Carpenter, S., Elmqvist, T., Gunderson, L., Holling, C.S. \& Walker B. (2002). Resilience and sustainable development: building adaptive capacity in a world of transformations. Ambio, 31(5), 437-440. DOI:10.1579/00447447-31.5.437.

Grabaum, R. \& Meyer B.Ch. (1998). Multicriteria optimization of landscapes using GIS-based functional assessments. Landsc. Urban Plann., 43, 21-34. DOI:10.1016/S0169-2046(98)00099-1.

Grabaum, R., Meyer, B.Ch., Friedrich, K., Wolf, T., Meyer, T. \& Gehrung J. (2005). Interactive user guide for the MULBO (in German). Leipzig: OLANIS Expertensysteme GmbH.

Holling, C.S. (1973). Resilience and stability of ecological systems. Annu. Rev. Ecol. Syst., 4, 1-23. DOI:10.1146/ annurev.es.04.110173.000245.

Igwe, C.A., Akamigbo F.O.R. \& Mbagwu J.S.C. (1999). Application of a SLEMSA and USLE erosion models for potential erosion hazard mapping in south-eastern Nigeria. International Agrophysics, 13, 41-48.

Koreleski, K. (2008). The influence of field factors on the intensity of water erosion exemplified by a mountain village (in Polish). Infrastructure and Ecology of Rural Areas, 3, 5-12.

Lastoria, B., Miserocchi, F., Lanciani, A. \& Monacelli G. (2008). An estimated erosion map for the Aterno-Pescara river basin. European Water, 21/22, 29-39.

Obrębska-Starklowa, B. (1983). Agroecological aspects of a mesoclimatic differentiation in the Lower Beskid (in Polish). Problemy Zagospodarowania Ziem Górskich, 23, 69-83.

Renard, K., Foster, G., Weesies, G., McCool D. \& Yoder D. (1997). Predicting soil erosion by water: a guide to conservation planning with the Revised Universal Soil Loss Equation (RUSLE). US: Agricultural Research Service.

Stone, R., Hilborn, D. (2000). Fact Sheet: Universal Soil Loss Equation (USLE). Retrieved November 13, 2012, from http://www.omafra.gov.on.ca/english/engineer/facts/00-001.htm

Tracz, P. (2004). Methods of assessment of environmental resilience to degradation using GIS techniques (in Polish). In M. Strzyż (Ed.), Perspective on the Regional Development in the Light of Landscape Research. The Problems of Landscape Ecology (pp. 277-285). Warsaw: PAEK.

Wischmeier, W.H. \& Smith D.D. (1978). Predicting rainfall erosion losses - a guide to conservation planning. Washington, DC: U.S. Department of Agriculture.

Yue-qing, X., Jian, P. \& Xiao-mei S. (2009). Assessment of soil erosion using RUSLE and GIS: a case study of Maotiao River watreshed, Guizhou Province, China. Environ. Geol., 56, 1643-1652. DOI:10.1007/s00254-008-1261-9. 